DOI 10.18551/rjoas.2021-08.14

\title{
CORRELATION COEFFICIENT AND PATH ANALYSIS FOR SEED WEIGHT SELECTION OF EX-SITU NUTMEG (MYRISTICA FRAGRANS HOUTT.) COLLECTION
}

\author{
Purwiyanti Susi* \\ Department of Agronomy and Horticulture, Faculty of Agriculture, IPB University \& \\ Indonesian Spice and Medicinal Crops Research Institute, Indonesian Agricultural Agency \\ for Research and Development (IAARD), Indonesia \\ Sudarsono, ORCID: 0000-0003-4688-5628 \\ Wahyu E.K. Yudiwanti, ORCID: 0000-0003-1966-5064 \\ Department of Agronomy and Horticulture, Faculty of Agriculture, IPB University, Indonesia

\section{Rostiana Otih} \\ Indonesian Spice and Medicinal Crops Research Institute, Indonesian Agricultural Agency for \\ Research and Development (IAARD), Bogor, West Java, Indonesia \\ ORCID: 0000-0002-8083-3963 \\ *E-mail: s.purwiyanti.81@gmail.com \\ ORCID: 0000-0003-0542-5916
}

\begin{abstract}
Nutmeg (Myristica fragrans Houtt.) is a perennial crop that yielded fruits about 5-7 years after planting. Determining the yield before the production phase required a considerable amount of time and was costly. The implementation of selection methods to observe characters that correlated to yields can shorten the selection period. Correlation and path analysis are methods used to select important characters that could be applied as marker-assisted selection based on morphological characters. Therefore, this research aims to observe the character as a selection criterion for seed weight in ex-situ nutmeg collections. The research was conducted at the ex-situ nutmeg collection garden at Cicurug Experimental Station, Sukabumi, West Java. The samples used were 104 females and 43 bisexual trees. The morphological characters observed were habitus, mature leaves, blooming flowers, ripe fruits, mace, and seeds. The relationship between characters was tested using Pearson correlation and continued with path analysis using the MINITAB 17 software. The results showed that the value of the correlation coefficient between fruits, seeds, and mace with the weight of the seeds was classified from strong to very strong and can be used for seed weight prediction. The selection of seed weight using the characters of fruit weight, fruit length, fruit diameter, mace weight, and seed length must be done simultaneously. While the selection with seed diameter character can be done independently.
\end{abstract}

\section{KEY WORDS}

Direct effect, fruit weight, indirect effect, reproductive, yield, vegetative.

Nutmeg is a perennial plant. The main products of nutmeg are fruits which consist of flesh, mace, and seeds. Nutmeg is harvested at about 5-7 years after planting. To find out the fruit yield potential takes a long time and a high cost. The yield is influenced by many characters. The implementation of selection methods to observe characters that correlated to yields can shorten the selection period. Correlation and path analysis is a method that can be applied to select morphological characters and yield components that affect the yield. In cocoa plant height, a number of secondary branches, and diameter, primary branch diameter can be used as selection criteria for assessing the yield (Wardiana and Pranowo 2020).

Correlation coefficients help determine which characters are important or not in the selection program. If a character and the response character are correlated, the improvement of characters which difficult to observe can be made by selecting other easily 
observed characters (Bakhtiar et al. 2010). Relationships among characters can be expressed by simple correlations. However, the simple correlation leads to misinformation due to the multicollinearity effect between characters. Moreover, the correlation coefficient cannot differentiate the direct and indirect effects of the characters. The weakness of correlation analysis can be solved by using path-analysis (Singh and Chaudary 1979).

Path analysis is a linear regression that shows the relationship effect of direct and indirect, through other characters (Singh and Chaudhary 1979). Path analysis provides information on the relationship between characters and explains the causal relationship between characters through separate paths constructed in a cross diagram. The use of correlation and path analysis in studying the relationship between quantitative characters is a guideline for a more efficient selection program (Wirnas et al. 2006). The use of correlation and path analysis to study the relationship between characters to yield and develop selection criteria has been carried out on various Cicer arientinum (Ali et al. 2009), Tamarindus indica (Okello et al. 2018), Theobroma cacao (dos Santos et al. (2018), Moringa oleifera (Karunakar et al. 2018), Macadamia integrefolia L. (Usha et al. 2018), Ricinus communis (Rofiq et al. (2019)), Cocos nucifera ((Miftahorrachman and Sulistyowati (2015); Mawardi et al. (2017)), Areca catechu (Miftahorrachman et al. 2019), and cotton (Rehman et al. 2020).

The high economic value of nutmeg is the high quality of seeds. The quality of nutmeg seeds includes the size, weight, and content of essential oils and myristicins. Several studies aimed at finding selection criteria for seed weight have been carried out. Vikram (2016) research showed that fruit weight was significantly positively correlated with fruit flesh, fruit volume, and thickness of pericarp. Further (Vikram, Miniraj, and Mathew 2018) evaluated 25 morphological characters of the nutmeg population in Kerala, India, by using path analysis to assess the yield potential of the fruits. However, their result has not specifically shown the important characters affected to the seed weight and the population used for analysis limited to the same ecotype. In the meantime, the expression of characters and their relationship is influenced by genetic and environmental factors. Usha et al. (2018) stated that environmental differences cause variability between different characters. Therefore correlation and pathanalysis are needed to assess ex-situ nutmeg collection, which is derived from different ecotypes. This study aimed to observe the characters as selection criteria for the seed weight of ex-situ nutmeg collections.

\section{MATERIALS AND METHODS OF RESEARCH}

The plant material used are nutmeg ex-situ collection at Cicurug Experimental Station, Sukabumi, West Java, of Indonesian Spices and Medicinal Crops Research Institute (ISMCRI). The samples used were 104 females and 43 bisexual nutmeg accessions, aged approximately 25 years. The characters observed were plant height, canopy width, stem circumference, branch internodes length, branch diameter, leaf length, leaf width, leaf thickness, leaf petiole length, corolla length, pedicels length, corolla diameter, pedicels diameter, fruit weight, fruit length, fruit diameter, fruit flesh thickness, mace weight, seed weight, seed length, seed diameter and fruit production per plant per year. The morphological characters were observed according to the Tropical Fruit Descriptors (IPGRI, 1980; Marzuki, 2007; Soeroso 2012). The number of samples observed for mature leaves, flowers, and ripe fruit, were 10 pieces for each tree. However, observation on habitus such as plant height, canopy width, and stem circumference were done only on a single tree its self. The data were analyzed by using Pearson correlation at $5 \%$ level. Correlation coefficient resulted from the data analysis were then classified according to Sarwono (2006). The significant value $(p>0.05)$ for seed weight were than evaluated by using path analysis. The correlation and path analysis were tested using the MINITAB 17 software.

\section{RESULTS AND DISCUSSION}

The correlation values ranged from 0.007 to 0.888 (Table 1), which implies a very weak to very strong correlation (Sarwono 2006). Gomez and Gomez (1984) stated the correlation 
value between two characters, close to -1 or +1 , which indicates a closer relationship. The significant positive correlation between characters shown between leaf length and width (0.495), corolla length with fruit production per plant per year $(0.475)$, fruit weight with fruit length (0.664), fruit diameter (0.888), fruit flesh thickness (0.523) and seed weight (0.531); fruit diameter with a fruit flesh thickness (0.653); fruit length with seed length (0.534); mice weight with seed weight (0.527); seed weight with seed length (0.588) and seed diameter (0.863); seed length with seed diameter (0.637). This research showed similar results with the research carried out by Vikram (2016), which showed that fruit weight was significantly positively correlated with fruit breadth, fruit volume, and thickness of pericarp. Positive correlation tends to increase or decrease in the same direction at the same time. In contrast, the significant negative correlation is indicated by the relationship between stem circumference with canopy width $(-0.637)$ and corolla length with corolla diameter $(-0.475)$.

Plant breeders widely use correlation analysis to conduct an indirect selection of main characters. In nutmeg, the weight of the seeds is one of the main characteristics that is used as a measure of quality. Therefore, it is very necessary to predict seed weight through other highly correlated and easily observable characters. The information on the correlation value in the ex-situ population can be used as a reference in the nutmeg selection program. The results of the correlation analysis on seed weight showed that six characters were significantly correlated, which are fruit weight $(0.531)$, fruit length $(0.402)$, fruit diameter (0.446), mace weight (0.527), seed length $(0.714)$, and seed diameter $(0.891)$. The value of the correlation coefficient between fruits, seeds, and mace with the weight of the seeds was classified from strong to very strong. Therefore, these characters can be used on seed weight prediction. The results of this research are similar to Anita-sari and Wahyu (2013), namely that the fruit weight and dry weight of cacao beans have a high and significant correlation.

Table 1 - Correlation matrix among morphological characters of ex-situ nutmeg collection

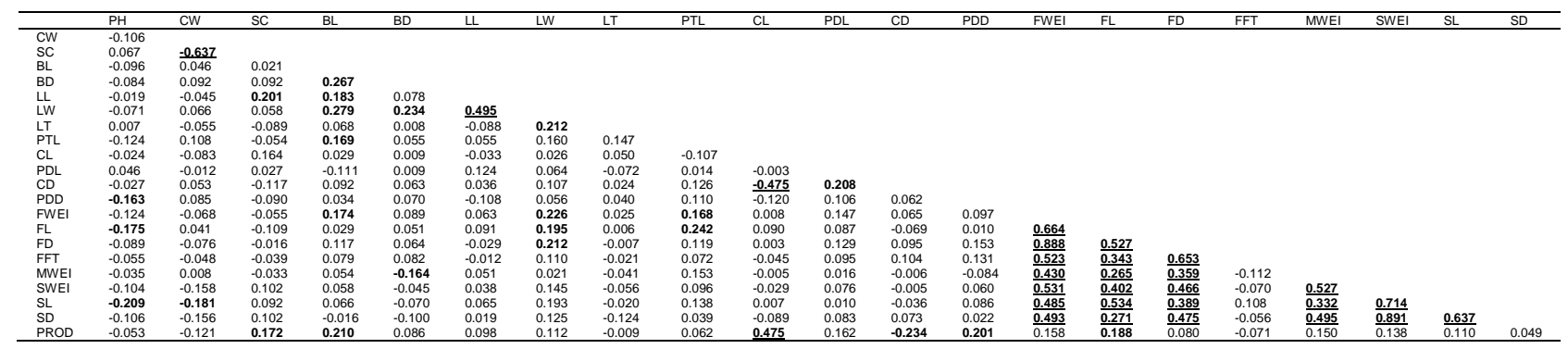

Note: Bold numbers show significant correlation at $\alpha=0.05$; bold and underline number show significant correlation at $\alpha=0.01$; $\mathrm{PH}=$ plant heigh; $\mathrm{CW}=$ canopy width; $S C=$ stem circumference; $B L=$ branch internodus length; $B D=$ branch diameter; $L L=$ leaf length; $L W=$ leaf width; $L T=$ leaf thickness; $P T L=$ leaf petiole length; $C L=$ corolla lenght; $P D L=$ pedicelluslenght; $C D=c o r o l l a$ diameter; $P D D=$ pedicellus diameter; $F W E I=$ fruit weight; $F L=$ fruit lenght; $F D=$ fruit diameter; $F F T=$ fruit flesh thickness; $M W E I=$ mace weight; $S W E I=$ seed weight; $S L=$ seed lenght; $S D=$ seed diameter; $P R O D=$ fruit production per plant per year.

Table 2 - Direct and indirect effect of the morphological character on the seed weight of ex-situ nutmeg collection

\begin{tabular}{lllllllll}
\hline \multirow{2}{*}{ Characters } & \multirow{2}{*}{ Direct effect } & \multicolumn{2}{l}{ Indirect effect } & & & & & \multirow{2}{*}{ Total effect } \\
\cline { 3 - 7 } & & FWEI & FL & FD & MWEI & SL & SD & 0.531 \\
FWEI & 0.065 & & 0.055 & -0.069 & 0.040 & 0.090 & 0.350 & 0.402 \\
FL & 0.083 & 0.043 & & -0.041 & 0.025 & 0.099 & 0.192 & 0.466 \\
FD & -0.078 & 0.058 & 0.044 & & 0.033 & 0.072 & 0.337 & 0.527 \\
MWEI & 0.093 & 0.028 & 0.022 & -0.028 & & 0.062 & 0.351 & 0.527 \\
SL & 0.186 & 0.032 & 0.045 & -0.030 & 0.031 & & 0.452 & 0.714 \\
SD & 0.709 & 0.032 & 0.023 & -0.037 & 0.046 & 0.118 & & 0.891 \\
\hline
\end{tabular}

Note :FWEl=fruit weight; $F L=$ fruit lenght; $F D=$ fruit diameter; $S L=$ seed lenght; $S D=$ seed diameter.

The information provides from path analysis concerning the direct and indirect effect of character observed as in table 2 . The fruit weight strongly correlates with seed weight (0.531), but the direct effect $(0.065)$ is low. There was also a strong correlation with fruit length, mace weight, and seed length, but this had a weak direct effect $(0.083,0.093,0.186)$. 
Fruit diameter is positively correlated with seed weight but has a negative value on the direct effect $(-0.078)$. It's due to the low direct influence of fruit weight, fruit length, fruit diameter, mace weight, and seed length. Therefore the seed weight selection must include all characters simultaneously. If the correlation between $X$ and $Y$ was positive, but the direct effect was negative or negligible, then the indirect effect might be due to the correlation itself (Singh and Chaudary 1979).

The highest correlation showed the relationship between seed diameter and weight (0.891). The value of the direct influence of the seed diameter on the seed weight is high (0.709) and is almost close to the correlation value. Therefore the seed weight estimation can be used as a marker-assisted selection without other characters. Singh and Chaudary (1979) stated that if the correlation coefficient between the independent and nonindependent variables remains positive and almost the same as the direct effect value, the correlation requires the correct relationship and the selection using characters effectively.

In this research, path analysis results showed that the selection of seed weight using the characters of fruit weight, fruit length, fruit diameter, mace weight, and seed length must be done simultaneously. While the selection with seed diameter character can be done independently.

In path analysis, there is a value that has not been calculated as a part of direct and indirect effect assessment (unidentified characters), it's called the residual value. The residual value calculated was $15.5 \%$. This means that the observed characters, $84.5 \%$, sufficiently represent the determination of direct and indirect effects among characters.

\section{CONCLUSION}

The value of the correlation coefficient between fruits, seeds, and mace with the weight of the seeds was classified from strong to very strong and can be used for seed weight prediction. The selection of seed weight using the characters of fruit weight, fruit length, fruit diameter, mace weight, and seed length must be done simultaneously. While the selection with seed diameter character can be done independently.

\section{REFERENCES}

1. Ali, Muhammad Amjad, Nausherwan Nobel Nawab, Amjad Abbas, M Zulkiffal, and M Sajjad. 2009. "Evaluation of Selection Criteria in Cicer arietinum L. Using Correlation Coefficients and Path Analysis." Australian J. Crop Sci. 3 (2): 65-70.

2. Anita-sari, Indah, and Agung Wahyu. 2013. "Pengembangan Kriteria Seleksi Karakter Berat Biji Pada Tanaman Kakao (Theobroma cacao L.) Melalui Pendekatan Analisis Sidik Lintas. Pelita Perkebunan 29 (3): 174-81.

3. Bakhtiar, Bambang S Purwoko, Trikoesoemaningtyas, and Iswari S Dewi. 2010. "Analisis Korelasi Dan Koefisien Lintas Antar Beberapa Sifat Padi Gogo Pada Media Tanah Masam." J. Floraktek 5: 86-93.

4. Gomez, KA, and AA Gomez. 1984. Statistical Procedures For Agricultural Research. New York (US) : John Wiley \& Sons, Inc.

5. Vikram, HC, N Mini Raj, K T Presanna Kumari, E V Nybe, D Mathew. 2016. "Variability in Fruit Characteristics of Nutmeg (Myristica Fragrans Houtt.) under Kerala Conditions." Journal of Spices and Aromatic Crops 25 (2): 187-94.

6. IPGRI, [International Plant Genetic Resources]. 1980. Tropical Fruits Descriptors. IBPGR Southeast Asia Regional Committee.

7. Karunakar J, Preethi TL, Boopathi N M, Pugalendhi L, Hepziba S J. 2018. "Genetic Variability, Correlation and Path Analysis in Moringa (Moringa oleifera L.)." Journal of Pharmacognosy and Phytochemistry 7 (5): 3379-82.

8. Marzuki, Ilyas. 2007. "Studi Morfo-Ekotipe Dan Karakterisasi Minyak Antsiri, Isozim, Dan DNA Pala Banda (Myristica Fragrans Houtt) Maluku." Dissertation. Bogor University [IN]

9. Mawardi, Sukmawati, Syenni Goniwala, and Miftahorrachman. 2017. "Sidik Lintas Karakter Komponen Buah Kelapa Dalam Pindolili." Buletin Palma 17 (2): 147-154. 
https://doi.org/10.21082/bp.v17n2.2016.147-154.

10. Miftahorrachman, NFN, Sukmawati Mawardi, and Ismail Maskromo. 2019. "Korelasi Dan Analisis Lintas Antara Karakter Agronomi Dengan Hasil Pada Pinang Emas (Areca catechu L.)." Buletin Palma 20 (1): 1. https://doi.org/10.21082/bp.v20n1.2019.1-9.

11. Miftahorrachman, and Emy Sulistyowati. 2015. "Analisis Heritabilitas Dan Sidik Lintas Karakter Vegetatif Dan Generatif Kelapa Genjah Salak Pada Tiga Sistim Persilangan.” B. Palma 16 (1): 93-103.

12. Okello, Jaspher, John Bosco Lamoris Okullo, Gerald Eilu, Philip Nyeko, and Joseph Obua. 2018. "Morphological Variations in (Tamarindus indica L.) Fruits and Seed Traits in the Different Agroecological Zones of Uganda." International Journal of Ecology 2018:112. https://doi.org/10.1155/2018/8469156.

13. Rehman, Abdul, Nida Mustafa, Xiongming Du, and Muhammad Tehseen Azhar. 2020. "Heritability and Correlation Analysis of Morphological and Yield Traits in Genetically Modified Cotton." Journal of Cotton Research 3 (1). https://doi.org/10.1186/s42397-02000067-z.

14. Rofiq, Ainur, Edy Kurniawan, and Budi Waluyo. 2019. Korelasi Dan Sidik Lintas Komponen Hasil Terhadap Hasil Tanaman Jarak Kepyar Lokal (Ricinus communis L.)." Jurnal Produksi Tanaman 7(1):8-16.

15. Santos, Emerson Alves dos, Alex Alan Furtado de Almeida, Marcia Christina da Silva Branco, Ivanildes Conceição dos Santos, Dario Ahnert, Virupax C. Baligar, and Raúl René Valle. 2018. "Path Analysis of Phenotypic Traits in Young Cacao Plants under Drought Conditions." PLoS ONE 13 (2): 1-16. https://doi.org/10.1371/journal.pone.0191847.

16. Sarwono, Jonathan. 2006. Metode Penelitian Kuantitatif Dan Kualitatif. Yogyakarta (IN): Graha IImu.

17. Soeroso, Sri Soenarsih Diah A. 2012. "Pala (Myristica Spp.) Maluku Utara Berdasarkan Keragaman Morfologi, Kandungan Atsiri, Pendugaan Seks Tanaman Dan Analisis Marka SSR." Dissertation. Bogor University [IN]

18. Usha, D.S., Nagarajappa A, Lakshamana D, Shivakumar B.S, and Thippesh D. 2018. "Correlation and Path-Coefficient Analysis of Yield and Selected Yield Components of Macadamia (Macadamia integrefolia ) Genotypes." Int. J. Pure App. Biosci 6 (5): 124-29.

19. Vikram, HC, N Miniraj, and Deepu Mathew. 2018. "Variability and Yield Contributing Principal Components in Nutmeg (Myristica fragrans Houtt.)." Indian Journal of Plant Genetic Resources 31 (3): 270. https://doi.org/10.5958/0976-1926.2018.00031.1.

20. Wardiana, Edi, and Dibyo Pranowo. 2020. "Selection of Vegetative and Generative Characters of Arabica Coffee By Using Sequential Path Analysis and Structural Equation Models." Jurnal Penelitian Tanaman Industri $20 \quad$ (2): 77. https://doi.org/10.21082/jlittri.v20n2.2014.77-86.

21. Wirnas, Desta, Imam Widodo, and Didy Sopandie. 2006. "Pemilihan Karakter Agronomi Untuk Menyusun Indeks Seleksi Pada 11 Populasi Kedelai Generasi F6 Selection of Agronomic Characters to Construct Selection Index on 11 Soybean Populations." Agronomi 24 (34): 19-24. 